膜タンパク質ストマチンの三次元構造とその特異的切断プロテアーゼの機能

\author{
横山英志
}

\title{
Three-dimensional Structure of Membrane Protein Stomatin and Function of Stomatin-specific Protease
}

\author{
Hideshi YoKOYAMA \\ Department of Physical Biochemistry, School of Pharmaceutical Sciences, University of Shizuoka, \\ 52-1 Yada, Suruga-ku, Shizuoka 422-8526, Japan
}

(Received May 29, 2010)

\begin{abstract}
Stomatin is a major integral membrane protein of human erythrocytes, the absence of which is associated with a form of hemolytic anemia known as hereditary stomatocytosis. It is reported that stomatin regulates the gating of acidsensing ion channels in mammalian neurons. However, the function of stomatin is not fully understood. In the genomic sequence of the hyperthermophilic archaeon Pyrococcus horikoshii, the putative operon-forming genes PH1511 and PH1510 encode stomatin and its partner protein, respectively. The N-terminal region of PH1510p (1510-N) is a serine protease, and specifically cleaves the C-terminal hydrophobic region of stomatin $\mathrm{PH} 1511 \mathrm{p}$. We have determined the first crystal structure of the core domain of stomatin PH1511p (residues 56-234, designated as PhSto ${ }^{\mathrm{CD}}$ ). This review focuses on the three-dimensional structure of $\mathrm{PhSto}{ }^{\mathrm{CD}}$, and discusses the function of stomatin and its specific protease $1510-N$. PhSto ${ }^{C D}$ forms a novel homotrimeric structure. Three $\alpha / \beta$ domains form a triangle of about $50 \AA$ on each side, and three $\alpha$-helical segments about $60 \AA$ in length extend from the apexes of the triangle. The $\alpha / \beta$ domain of PhSto ${ }^{\mathrm{CD}}$ is partly similar in structure to the band-7 domain of mouse flotillin-2. While the $\alpha / \beta$ domain is relatively rigid, the $\alpha$-helical segment shows a conformational flexibility, adapting to the neighboring environment. One $\alpha$-helical segment forms an anti-parallel coiled-coil with another $\alpha$-helical segment from a symmetry-related molecule. The $\alpha$-helical segment shows a heptad repeat pattern, and mainly hydrophobic residues form a coiled-coil interface. The coiled-coil fold observed in the crystal probably contributes to the self-association.
\end{abstract}

Key words_— stomatin; crystal structure; coiled-coil; Pyrococcus horikoshii; flotillin

\section{1. はじめに}

ストマチンは，ヒトの赤血球膜上で発見され脂質 ラフトに存在する膜タンパク質であり，そのタンパ ク質が欠損すると遺伝性有口赤血球症 stomatocytosis を引き起こす。この疾患は, $\mathrm{Na}^{+}$や $\mathrm{K}^{+}$などの イオンが生体膜を異常に透過することが原因と考え られることから，ストマチンはイオンチャネルの制 御因子と考えられてきた. ${ }^{1,2)}$ 近年, 哺乳動物の神経 細胞に存在する電位非依存性のナトリウムチャネル である酸感受性イオンチャネルの開閉をストマチン が制御することが報告された. ${ }^{3)}$ またストマチン様

静岡県立大学薬学部生命物理化学分野 ( $=422-8526$ 静 岡市駿河区谷田 52-1)

e-mail: h-yokoya@u-shizuoka-ken.ac.jp

本総説は, 平成 21 年度日本薬学会東海支部学術奨励賞 の受賞を記念して記述したものである.
タンパク質（Stomatin-like protein 3, SLP3）が皮膚

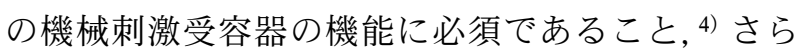
に線虫のストマチンオルソログ MEC-2 が接触感覚 受容器と相互作用しその活性を制御すること5)も報 告されている。

ヒトのストマチンは，アミノ（N）末側に膜貫通 領域とパルミトイル化されたシステイン残基があつ て生体膜に強く会合しており, 6) 分子量 250-300 kDa の 9-12 量体を形成している7) と報告されてい る.またカルボキシ（C）末側にある疎水性領域が 多量体形成に重要でありその領域が生体膜との会合 に必須であるとの報告もある。 ${ }^{8)}$ ストマチンの分子 レベルでの機能は解明されていないが，脂質ラフト に局在し多量体の足場タンパク質やシグナル伝達物 質として機能するのではないかと予想される.

ストマチンはほとんどすべての種にそのオルソロ 


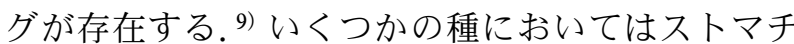
ンとそのパートナー遺伝子がオペロンを作ってい る. ${ }^{2)}$ 超好熱菌 Pyrococcus horikoshii では PH1511p がストマチン，PH1510p がパートナータンパク質 である。われわれは PH1511p と PH1510p の構造 と機能の解明を目指し，ストマチン PH1511p のコ アドメインの三次元構造を $\mathrm{X}$ 線結晶構造解析によ り初めて明らかにした。. ${ }^{10)}$ さらにPH1510p の N 末 側可溶性ドメイン（1510-N） は，触媒残基として Ser-Lys dyad を有するセリンプロテアーゼであり， 疎水性残基を好んで切断することを明らかにし

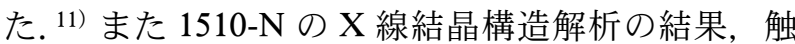
媒残基が疎水性ポケットを形成しており疎水性残基 を取り込むのに適した構造になっていることも明ら かにした. ${ }^{12)}$ 興味深いことに 1510-N はストマチン PH1511p の C 末側にある疎水性領域を特異的に切 断する. ${ }^{11)}$ 本総説では，ストマチンのコアドメイン の三次元構造とその特異的切断プロテアーゼ
1510-N との機能相関について述べる.

\section{2. ストマチンコアドメインの全体構造}

アミノ酸配列情報から PH1511p は $\mathrm{N}$ 末側に 2 回 膜貫通領域を有すると考えられる膜タンパク質であ る. その三次元構造を決定するため，全長 266 残基 中， $\mathrm{N}$ 末側の膜貫通領域と $\mathrm{C}$ 末側の疎水性領域を 除いた 56-234 残基 (Pyrococcus horikoshii Stomatin Core Domain, PhSto ${ }^{\mathrm{CD}}$ ) について，大腸菌発現 系によりタンパク質を調製し，セレノメチオニン置 換体を用いて X 線回折強度デー夕を収集し，多波 長異常分散法により分解能 $3.2 \AA$ で構造を決定した (PDB : 3bk6). ${ }^{10)}$

得られた PhStocD はホモ三量体で，各モノマー は 56-169 残基からなる $\alpha / \beta$ ドメインと 170 残基以 降からなる $\alpha$ ヘリカルセグメントから構成される [Figs. 1 (a) and (b) ]. PhSto ${ }^{\mathrm{CD}}$ の三量体のうち A 鎖は 56-224 残基，B 鎖は 56-196 残基，C 鎖は 56214 残基までの構造が決定できた。 $\alpha / \beta$ ドメインは (a)

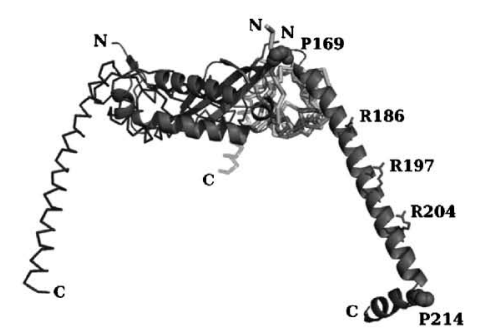

$90^{\circ}$

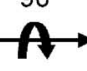

(b)

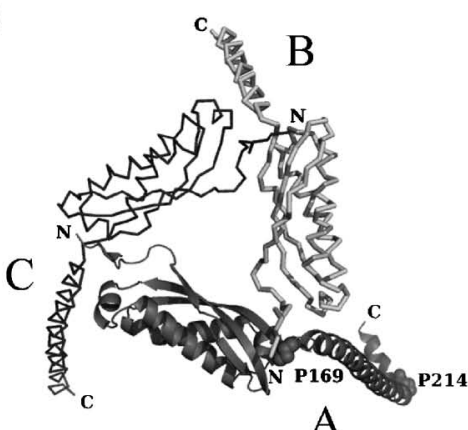

A

(d)

(c)

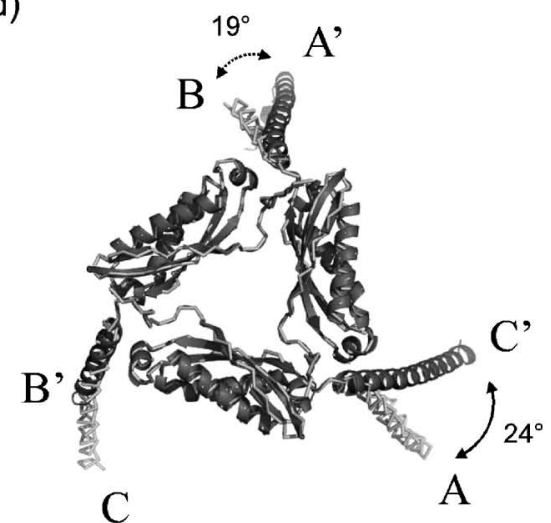

Fig. 1. Overall Structure of PhSto ${ }^{\mathrm{CD}}$ Trimer

(a) Side view. (b) Top view. (c) The secondary structure elements are labeled with the monomer (chain A) of PhSto ${ }^{\mathrm{CD}}$. (d) Superposition of the C $\alpha$ traces of PhSto ${ }^{\mathrm{CD}}$ protomers. The $\alpha / \beta$ domain (residues 56-169) of chain A is superposed on that of chain $\mathrm{B}$, and the superposed chain $\mathrm{A}$ is labeled as chain $\mathrm{A}^{\prime}$. The same superpositions were performed: chain B to chain C (labeled as chain $\mathrm{B}^{\prime}$ ), and chain $\mathrm{C}$ to chain $\mathrm{A}$ (labeled as chain $\mathrm{C}^{\prime}$ ). 
$\mathrm{N}$ 末から $\beta 1, \beta 2, \beta 3 \beta 4, \alpha 1, \alpha 2, \alpha 3, \alpha 4, \beta 5, \beta 6$ の順に 並んでいる [Fig. 1(c)]．3つの $\alpha / \beta$ ドメインは一 辺 $50 \AA$ ，高さ $20 \AA$ の三角形を形成しており，逆平 行 $\beta$ ストランド（ $\beta 2-\beta 6 ）$ は連続した $\alpha$ ヘリックス $(\alpha 1-\alpha 4)$ に取り囲まれるように位置している， $\alpha$ へ リカルセグメントは長さ $60 \AA$ A 11 ターンの長い $\alpha 5$ ヘリックスから主に構成されている， $\alpha 5$ の両端に は Pro-169 と Pro-214 がありそこでへリックスは大 きく折れ曲がっている.

2つのモノマー間の接触面積はそれぞれ異なり， 1600-1800 $\AA^{2}$ となっている。接触部分において一 方のモノマーの $\beta 1$ と $\alpha 1$ が他方のモノマーの $\beta 6$ と $\alpha 5$ と相互作用している。 $\alpha / \beta$ ドメインの各モノ マー同士の $\mathrm{C} \alpha$ 原子を重ね合わせた場合，どの場合 もその根二乗平均偏差（root mean square deviation， R.M.S.D.) は $0.4-0.5 \AA$ 程度と小さく，よく重な る。一方， $\alpha$ ヘリカルセグメントの $\mathrm{C} \alpha$ 原子を各モ ノマー同士で重ね合わせた場合， A 鎖と B 鎖とで は R.M.S.D. $1.82 \AA$, C 鎖とA 鎖とでは R.M.S.D. $2.31 \AA$ と大き,$\alpha / \beta$ ドメインの三角形の各頂点を 基点としてそれぞれ $19^{\circ}, 24^{\circ}$ も傾いている $[$ Fig. 1 (d)］。これらの構造の差異については次章で述べ る.

Protein Data Bank に登録されている構造から $\mathrm{PhSto}^{\mathrm{CD}}$ の構造と類似構造がないか検索したとこ ろ, マウス由来フロチリン-2 の band-7 ドメインの 構造（PDB : 1 win）が $\mathrm{PhSto}^{\mathrm{CD}}$ の $\alpha / \beta$ ドメインの 構造と類似していることが分かった。フロチリンは ストマチンと同じ SPFH ファミリー（StomatinProhibitin-Flotillin-HflK/C）に属するタンパク質 で，そのうちフロチリン-1 はクラスリン非依存性 エンドサイトーシスの制御因子であり，13) フロチリ ン-2 は膜小胞輸送の機能に関与することが報告さ れている. ${ }^{14)}$ 最近, 赤血球の貯蔵中に生じる膜小胞 中にストマチンが多量に含まれることからストマチ ンが膜小胞形成に関与することが報告されてい る. ${ }^{15)}$ フロチリンとストマチンは構造が類似してお り膜小胞形成に関与するなど共通点がみられる.

3. コイルドコイル構造と生体膜との相互作用モ デル

$\mathrm{PhSto}^{\mathrm{CD}}$ の結晶構造において $\mathrm{A}$ 鎖の $\alpha 5$ ヘリック スは結晶中の隣の分子の $\mathrm{C}$ 鎖の $\alpha 5$ ヘリックスと逆 平行にコイルドコイル相互作用している [Figs. 2 (a) and (b) ]. $\alpha 5$ ヘリックスは Fig. 2(c)のヘリカルホ イール図で heptad repeatパターンを示している，a と $d$ の位置には疎水性残基が集中しており，結晶 中で隣り合う分子の $\alpha 5$ ヘリックス同士が $a$ と $d$ の 位置の疎水性残基を介して相互作用している. 一方, $\alpha 5$ ヘリックスの $c, f, g$ の位置には極性残基が多く 存在し，溶媒に露出していると考えられる．2つの $\alpha 5$ ヘリックス同志の分子間の接触面積は $1800 \AA^{2}$ であり, 各モノマー間の接触面積と同程度である. 結晶構造中で, $\mathrm{B}$ 鎖の $\alpha 5$ ヘリックスはほかとの相 互作用がみられないが， $\mathrm{A}$ 鎖と $\mathrm{C}$ 鎖の $\alpha 5$ ヘリック スはコイルドコイル相互作用するため Fig. 1 (d) に みられるように $\alpha / \beta$ ドメインの三角形の各頂点を 基点として構造が変化すると考えられる．またこの ことから， $\alpha 5$ ヘリックスは $\alpha / \beta$ ドメインに比べて 柔軟性が高く, 周辺の環境に応じて大きく構造変化 することが可能であると考えられる.

$\mathrm{PhSto}^{\mathrm{CD}}$ の $\mathrm{N}$ 末には疎水性残基が存在してお り，その先に PH1511p の 2 回膜貫通領域が存在す ると考えられることから, Fig. 1 (a) で $\alpha / \beta$ ドメイ ンの上側が生体膜と相互作用すると考えられる。 ま た $\alpha 5$ ヘリックスの外側には正電荷を帯びたアルギ ニン残基（Arg-186, Arg-197, Arg-204）が存在して いる [Fig. 1(a)]。 $\alpha 5$ ヘリックスが $\alpha / \beta$ ドメインの 三角形の各頂点を基点として動くことにより，これ らのアルギニン残基が生体膜の負電荷を帯びたリン 酸基と静電相互作用するのではないかと予想され る。近年，ストマチン様タンパク質（Stomatin-like protein 2, SLP2) が，ミトコンドリアの膜融合に係 わる mitofusin-2 とへテロ多量体を形成することが 報告されている. ${ }^{16)}$ ストマチン PH1511p の $\alpha 5$ ヘリ ックスが生体膜に相互作用し，ストマチン分子同 士，若しくはストマチンと他の分子が $\alpha 5$ ヘリック スを介したコイルドコイル相互作用により会合し， SLP2 のように膜融合の機能に関与するのかもしれ ない.

4. ストマチン多量体とプロテアーゼによる切断 PH1511p とヒトのストマチンはアミノ酸配列の 相同性が $43 \%$ と比較的高い。ヒトのストマチンは 多量体を形成しており，C末側の 264-272 残基 ${ }^{264}$ STIVFPLPI272) が多量体形成に重要であると報 告されている. ${ }^{8)}$ PH1511p においては 234-242 残基 $\left({ }^{234}{ }^{2}\right.$ VIVLMLPM $\left.{ }^{242}\right)$ がその領域に相当する（Fig. 
(a)

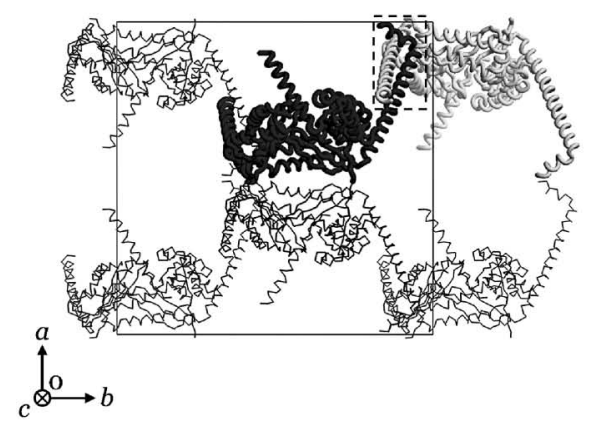

(b)

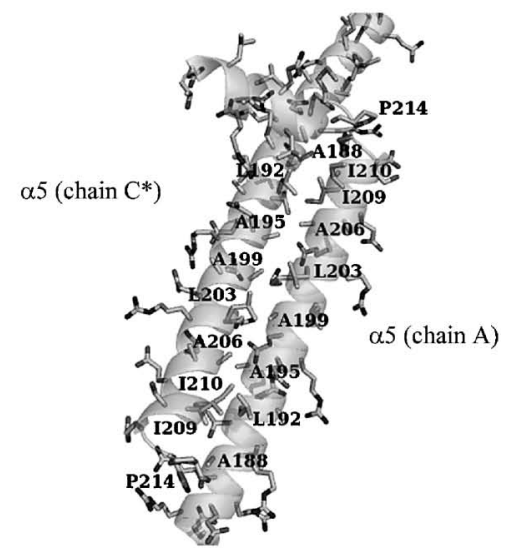

(c)

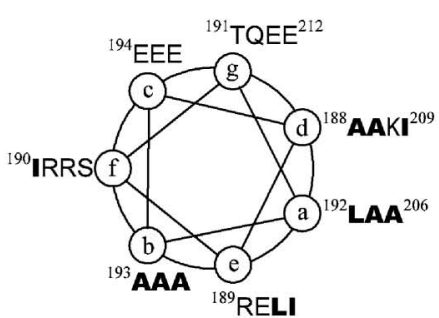

Fig. 2. Coiled-coil interaction

(a) Crystallographic symmetry-related molecules of $\mathrm{PhSto}{ }^{\mathrm{CD}}$ with a unit cell. (b) Close-up view of the region surrounded by the dotted frame in (a). One $\alpha 5$ (chain A) interacts with another $\alpha 5$ (chain C) of a symmetry related molecule (indicated as asterisk). (c) Residues 188 to 212 of $\alpha 5$ are projected onto helical wheels in the clockwise direction from residue 188. Bold letters show hydrophobic residues.

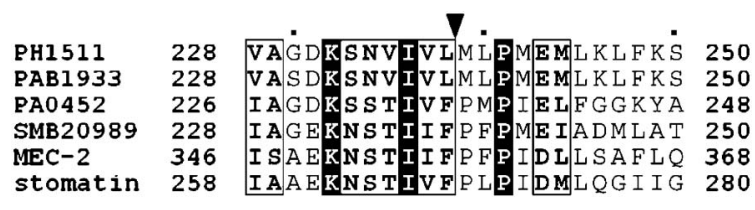

Fig. 3. Sequence Alignment of C-terminal Amino Acids for Stomatin Orthologs

Abbreviations are as follows: PH1511 (from P. horikoshii), PAB1933 (P. abyssi), PA0452 (Pseudomonas aeruginosa), SMB20989 (Sinorhizobium meliloti), MEC-2 (Caenorhabditis elegans), and stomatin (human). White lettering boxed with a black background indicates residues that are conserved in all sequences, and bold lettering indicates similar residues. A filled arrowhead shows proteolytic cleavage site of PH1511p by the 1510-N protease. Underlined residues of human stomatin are crucial for oligomarization.

3).

興味深い点としてこの多量体形成に関与する領域

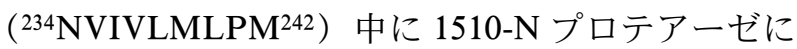
よる切断部位が存在する. 1510-N プロテアーゼは, PH1511p の Leu-238 と Met-239 の間で特異的に切 断する $\left({ }^{234} \mathrm{NVIVL} \downarrow \mathrm{MLPM}^{242}\right) .{ }^{11)}$ またヒトのスト マチンにおいて, Ile-266, Val-267, Phe-268 の 3 つ
の残基が生体膜との相互作用に必須であるとの報告 もある. ${ }^{8)}$ PH1511p においては，Ile-236, Val-237, Leu-238 がそれらの残基に相当する。 これらの 3 つ の残基は 1510-N プロテアーゼによる切断部位のす ぐ前の残基である．高次の多量体を形成すると考え られるストマチン PH1511p は，1510-N プロテアー ゼにより切断を受けると, 生体膜上の多量体が解離 し，その構造変化がなんらかの情報伝達に関与する のではないかと予想される.

\section{5. おわりに}

本総説では，ストマチン PH1511p のコアドメイ ン $\mathrm{PhSto}^{\mathrm{CD}}$ の三次元構造を中心とし, その特異的 切断プロテアーゼ 1510-N との関連について紹介し た．ストマチンの三次元構造を初めて決定できたた め, これらのタンパク質の機能解明の手がかりが得 られたと考えている. しかし決定した $\mathrm{PhSto}{ }^{\mathrm{CD}}$ の 結晶構造は，1510-N プロテアーゼによる切断部位 を含んでいないことから，PH1511p の多量体構造 ではなく，むしろ 1510-N による切断後の構造であ 
ると考えられる，今後，1510-Nによる切断部位を 含めたストマチン PH1511p の多量体構造を決定す ることができれば，ストマチンの本質的な機能の解 明につながると期待できる。

最近，真核生物の巨大核酸-タンパク質複合体で ある vault の三次元構造が X 線結晶構造解析により 決定された。 ${ }^{17)}$ vault は分子量が約 1000 万で多剤耐 性や自然免疫への関与が報告されているが本質的な 機能は明らかになっていない。興味深いことに，こ の vault の肩ドメインの構造がストマチン PhSto ${ }^{\mathrm{CD}}$ の構造と類似していた，vault が脂質ラフトへ集合 する現象が報告されていることから ${ }^{18)}$ 両者の機能的 な関連に興味が持たれる。

謝辞本研究は, 産業技術総合研究所の松井郁 夫博士との共同研究で行われたものです，本研究を 行うにあたり，多大なご指導とご助言を賜りました 松井博士には心より感謝申し上げます。さらにご懇 切なご指導, ご鞭撻を賜りました静岡県立大学薬学 部の藤井敏教授に謝意を表します。また構造解析を 行うにあたりご助言を頂きました産業技術総合研究 所の原田一明博士，秋葉俊彦博士，並びに，X 線 回折強度データの収集を行う際お世話になりました つくば高エネルギー加速器研究機構のスタッフの皆 様に感謝いたします。最後に，貴重なご助言とご協 力を頂いた産業技術総合研究所の松井研究室の皆 様, 静岡県立大学薬学部の教室員の皆様に御礼申し 上げます。

\section{REFERENCES}

1) Stewart G. W., Argent A. C., Dash B. C., Biochim. Biophys. Acta, 1225, 15-25 (1993).

2) Green J. B., Fricke B., Chetty M. C., von Düring M, Preston G. F., Stewart G. W., Blood Cells, Mol. Dis., 32, 411-422 (2004).

3) Price M. P., Thompson R. J., Eshcol J. O., Wemmie J. A., Benson C. J., J. Biol. Chem., 279, 53886-53891 (2004).

4) Wetzel C., Hu J., Riethmacher D., Benckendorff A., Harder L., Eilers A., Moshourab R.,
Kozlenkov A., Labuz D., Caspani O., Erdmann B., Machelska H., Heppenstall P. A., Lewin G. R., Nature (London) , 445, 206209 (2007).

5) Goodman M. B., Ernstrom G. G., Chelur D. S., O'Hagan R., Yao C. A., Chalfie M., Nature (London), 415, 1039-1042 (2002).

6) Snyers L., Umlauf E., Prohaska R., FEBS Lett., 449, 101-104 (1999).

7) Snyers L., Umlauf E., Prohaska R., J. Biol. Chem., 273, 17221-17226 (1998).

8) Umlauf E., Mairhofer M., Prohaska R., $J$. Biol. Chem., 281, 23349-23356 (2006).

9) Tavernarakis N., Driscoll M., Kyrpides N. C., Trends Biochem. Sci., 24, 425-427 (1999).

10) Yokoyama H., Fujii S., Matsui I., J. Mol. Biol., 376, 868-878 (2008).

11) Yokoyama H., Matsui I., J. Biol. Chem., 280, 6588-6594 (2005).

12) Yokoyama H., Matsui E., Akiba T., Harata K., Matsui I., J. Mol. Biol., 358, 1152-1164 (2006)

13) Glebov O. O., Bright N. A., Nichols B. J., Nat. Cell Biol., 8, 46-54 (2006).

14) Langhorst M. F., Reuter A., Jaeger F. A., Wippich F. M., Luxenhofer G., Plattner H., Stuermer C. A., Eur. J. Cell Biol., 87, 211-226 (2008)

15) Salzer U., Zhu R., Luten M., Isobe H., Pastushenko V., Perkmann T., Hinterdorfer P., Bosman G. J., Transfusion, 48, 451-462 (2008).

16) Hájek P., Chomyn A., Attardi G., J. Biol. Chem., 282, 5670-5681 (2007).

17) Tanaka H., Kato K., Yamashita E., Sumizawa T., Zhou Y., Yao M., Iwasaki K., Yoshimura M., Tsukihara T., Science, 323, 384-388 (2009)

18) Kowalski M. P., Dubouix-Bourandy A., Bajmoczi M., Golan D. E., Zaidi T., CoutinhoSledge Y. S., Gygi M. P., Gygi S. P., Wiemer E. A., Pier G. B., Science, 317, 130-132 (2007) 